\title{
Biodegradation of endocrine disruptor dibutyl phthalate (DBP) by a newly isolated Methylobacillus sp. V29b and the DBP degradation pathway
}

\author{
Vinay $\operatorname{Kumar}^{1} \cdot$ S. S. Maitra ${ }^{1}$
}

Received: 5 August 2016/Accepted: 14 September 2016/Published online: 21 September 2016

(C) The Author(s) 2016. This article is published with open access at Springerlink.com

\begin{abstract}
Bacteria of the genus Methylobacillus are methanotrophs, a metabolic feature that is widespread in the phylum Proteobacteria. The study demonstrates the isolation and characterization of a newly isolated Methylobacillus sp. V29b. which grows on methanol, protocatechuate, monobutyl phthalate, dibutyl phthalate, diethyl phthalate, benzyl butyl phthalate, dioctyl phthalate and diisodecyl phthalate. Methylobacillus sp. V29b was characterized with scanning electron microscopy, transmission electron microscopy, Gram staining, antibiotics sensitivity tests and biochemical characterization. It degrades $70 \%$ of the initial DBP in minimal salt medium and $65 \%$ of the initial DBP in samples contaminated with DBP. DBP biodegradation kinetics was explained by the Monod growth inhibition model. Values for maximum specific growth rate $\left(\mu_{\max }\right)$ and half-velocity constant $\left(K_{\mathrm{s}}\right)$ are $0.07 \mathrm{~h}^{-1}$ and $998.2 \mathrm{mg} / \mathrm{l}$, respectively. Stoichiometry for DBP degradation was calculated for Methylobacillus sp. V29b. Four metabolic intermediates, dibutyl phthalate (DBP), monobutyl phthalate, phthalic acid and pyrocatechol, were identified. Based on the metabolic intermediates identified, a chemical pathway for DBP degradation was proposed. Six genes for phthalic acid degradation were identified from the genome of Methylobacillus sp. V29b.
\end{abstract}

Keywords Endocrine disruptor - Degradation kinetics . Stoichiometry · Gene identification · Phthalate ester degradation pathway

Vinay Kumar

vkmjnu@gmail.com

1 Lab No. 117, School of Biotechnology, Jawaharlal Nehru University, New Delhi 110067, India

\section{Introduction}

Phthalic acid esters (PAEs) are a class of compounds widely used as plasticizers to provide mechanical strength and flexibility to the resins (Cartwright et al. 2000; Staples et al. 1997). They are ingredients of paints, adhesives, house-building materials, defoaming agents, PVC pipes, food packing materials, toys, plastics, solubilizers of cosmetic products, medical devices, photography films, textile fabrics, pesticide carriers, lubricating oils and are used in aerospace technology (Gesler 1973; Gross and Colony 1973; Hauser et al. 2007; Ito et al. 2005; Krauskopf 1973; Marcel 1973; Teil et al. 2006; Tepper 1973; Wang et al. 1995b; Wilkinson and Lamb 1999). They have low solubility in water; therefore, they are stable in the environment over a longer period of time (Huang et al. 2008; Vikelsøe et al. 2002; Wang et al. 2008; Yuan et al. 2002). They have been detected in various environments including landfill leachates (Schwarzbauer et al. 2002; Zheng et al. 2007), air (Wensing et al. 2005), soils, sediments, and natural waters (Staples et al. 1997). PAEs have been classified as top priority toxicants by the European Union, China National Environmental Monitoring Center and US Environment Protection Agency (Chen et al. 2007; Council of the European Union 1993). PAEs are responsible for carcinogenicity and endocrine disruption (Colborn et al. 1993; David et al. 1999; Jobling et al. 1995; Piersma et al. 2000). They can elicit cellular estrogenic responses and suppress calcium signaling (Kaun-Yu et al. 2004; Lovekamp-Swan and Davis 2003; Moore 2000). They are responsible for hypospadias, cryptorchidism and malformation of the reproductive tract in mice (Fisher 2004; Gray et al. 2000; Jaeger and Rubin 1970; Li et al. 1998; Zhu et al. 2006). They are known for irritation of eyes, skin, respiratory tract, blurred vision and induce stone formation in the 
bladder (Dai et al. 2005a, b; Wang and Gu 2006). Dibutyl phthalate (DBP) is the most widely used plasticizer and has been detected in different environments (Eaton 2001; Feiler 1980; Hashizume et al. 2002; Keith and Telliard 1979; $\mathrm{Xu}$ et al. 2005).

The natural processes of degradation such as hydrolysis and photodecomposition are not efficient in the degradation of these pollutants ( $\mathrm{Lu}$ et al. 2009). Therefore, microbial degradation is the major route for their degradation (Staples et al. 1997; Vamsee-Krishna et al. 2006; VamseeKrishna and Phale 2008). Bacteria having potential to degrade PAEs have been isolated from various environments including mangrove sediments, activated sludge and wastewater (Liang et al. 2008). Aerobic degradation of PAEs is much more efficient as compared to anaerobic degradation (Cheung et al. 2007; Fang et al. 2010). Sequential hydrolysis of PAEs has been demonstrated by a few researchers (Engelhardt and Wallnöfer 1978; Jiao et al. 2013; Staples et al. 1997).

Despite research on degradation of PAEs by various researchers, these studies lack in perspectives such as efficient DBP degradation at higher concentrations, elucidation of DBP degradation pathway, kinetics of DBP degradation and identification of genes responsible for PAEs degradation. Extensive research in the above aspects is required to remove these pollutants from the environment. The aim of the study was isolation, characterization and identification of efficient DBP-degrading bacterial strain from municipal solid waste (MSW) leachate and to examine the degradation potential of the isolate toward degradation of DBP in both minimal media and in PAEscontaminated samples collected from the landfill site.

\section{Materials and methods}

\section{Chemicals}

HPLC-grade monobutyl phthalate, diisodecyl phthalate, dioctyl phthalate, protocatechuate, benzyl butyl phthalate, diethyl phthalate and dibutyl phthalate were purchased from Sigma-Aldrich (USA) and used as substrate for growth of the bacteria. HPLC-grade acetonitrile purchased from Sigma-Aldrich (USA) was used as solvent in the analysis of DBP.

\section{Isolation and characterization of DBP-degrading bacteria}

Municipal solid waste (MSW) leachate samples were collected from a municipal solid waste landfill site at Ghazipur, New Delhi, India. The location co-ordinates of Ghazipur landfill site are $28^{\circ} 37^{\prime} 22.4^{\prime \prime} \mathrm{N}$ and $77^{\circ} 19^{\prime}$
25.7"E. The physical parameters of the site are: $\mathrm{pH} 8.4$, TDS 29,700, COD 31,600, Fe 9.81 and $\mathrm{Cl} 1174.2$. After collection, the samples were stored at $4{ }^{\circ} \mathrm{C}$. The MSW leachate was inoculated in minimal salt medium (MSM) supplemented with DBP [DBP emulsified with $0.1 \%$ (vol/vol) Tween 80] as the sole carbon and energy source. MSM was prepared by dissolving $3.5 \mathrm{~g} \mathrm{~K}_{2} \mathrm{HPO}_{4}, 1.5 \mathrm{~g}$ $\mathrm{KH}_{2} \mathrm{PO}_{4}, 0.27 \mathrm{~g} \mathrm{MgSO}_{4}, 1 \mathrm{~g} \mathrm{NH}_{4} \mathrm{Cl}, 0.03 \mathrm{~g} \mathrm{Fe}_{2}\left(\mathrm{SO}_{4}\right)_{3}$ $7 \mathrm{H}_{2} \mathrm{O}$ and $0.03 \mathrm{~g} \mathrm{CaCl}_{2}$ in $1 \mathrm{~L}$ distilled water. The $\mathrm{pH}$ of MSM was adjusted to 6.8 and sterilized by autoclaving at $121^{\circ} \mathrm{C}$ and $15 \mathrm{psi}$ for $20 \mathrm{~min}$. A separate iron sulfate and magnesium sulfate solution was prepared, filter sterilized with $0.22 \mu \mathrm{m}$ membrane filter and added to MSM to avoid precipitate formation (Vega and Bastide 2003). For isolation of DBP-degrading bacteria, $1 \mathrm{ml}$ MSW leachate was inoculated to $100 \mathrm{ml}$ MSM supplemented with $10 \mathrm{mg} / \mathrm{l}$ of DBP and incubated at $30^{\circ} \mathrm{C}$ and $180 \mathrm{rpm}$. The amount of DBP was increased in subsequent transfer cultures. Culture from the flask was streaked on MSMagar plates to obtain a pure culture. A colony numbered 29 was able to grow in the presence of DBP and it was designated as strain 29D. Size and cell morphology were observed using scanning electron microscopy (SEM). Internal features of the bacteria were observed using transmission electron microscopy (TEM). SEM and TEM of strain 29D were performed at the Advanced Instrumentation Research Facility (AIRF), Jawaharlal Nehru University, New Delhi. For electron microscopy, bacterial cells were fixed in $3 \%$ glutaraldehyde at room temperature for $3 \mathrm{~h}$. After fixation, bacterial cells were washed with $0.1 \mathrm{M}$ phosphate buffer thrice for $10 \mathrm{~min}$. Post-fixation was performed in 1-2\% osmium tetroxide solution followed by dehydration with increasing concentrations of ethanol in water solution (Smith 1955). Characterization of strain 29D was performed using biochemical tests (Vos et al. 2011). Gram staining reaction was performed using Gram-stain kit from Himedia Lifesciences. Determination of catalase activity was performed by assessment of bubble production in $3 \%(\mathrm{v} / \mathrm{v}) \mathrm{H}_{2} \mathrm{O}_{2}$. Determination of oxidase activity was performed using $1 \%(\mathrm{w} / \mathrm{v})$ tetramethyl-p-phenylenediamine from Himedia lifesciences. Hydrolysis of starch was determined by growing bacteria on MSM plates containing $0.2 \%(\mathrm{w} / \mathrm{v})$ starch. Susceptibility to antibiotics was determined by spreading the bacterial suspension on MSM plates amended with $10-100 \mu \mathrm{g} / \mathrm{ml}$ of antibiotic tested. To assess the capability of strain 29D to cleave the benzene ring, Rothera's test was performed. For the test, $5 \mathrm{ml}$ of bacterial culture was saturated with solid ammonium sulfate and mixed with a few drops of $2 \%$ sodium nitroprusside solution and liquor ammonia. The mixture was left for $15 \mathrm{~min}$. A bluish-purple ring indicates the presence of the ketone bodies in it (Rothera 1908). 
16S-rRNA gene amplification, sequencing and phylogenetic analysis

Identification of strain 29D was performed by 16S-rRNA gene identification. Genomic DNA of the strain 29D was isolated using Fast DNA ${ }^{\circledR}$ SPIN Kit for soil from MP Bio. The $16 \mathrm{~S}-$ rRNA gene amplification was performed with bacterial universal primers 27F and 1492R (Weisburg et al. 1991). For PCR, a $50 \mu \mathrm{l}$ reaction was used containing $25 \mu \mathrm{l}$ PCR master mix (Thermo Scientific), $2 \mu$ l forward primer, $2 \mu$ l reverse primer, $23 \mu \mathrm{l}$ sterile water and $1 \mu \mathrm{l}$ genomic DNA. Time programming used for the thermo cycler (Applied Biosystems Gene Amp PCR system 9700) was 10 min at $95{ }^{\circ} \mathrm{C}, 35$ cycles, $60 \mathrm{~s}$ at $95{ }^{\circ} \mathrm{C}, 90 \mathrm{~s}$ at $54{ }^{\circ} \mathrm{C}$, and $60 \mathrm{~s}$ at $72{ }^{\circ} \mathrm{C}$ and $5 \mathrm{~min}$ at $72{ }^{\circ} \mathrm{C}$. The amplified PCR product was gel purified with HiYield $^{\text {TM }}$ PCR DNA Mini Kit from Real Genomics ${ }^{\text {TM }}$ (Ref catalog no. YDF100). Sequencing of the purified product was performed at the DNA sequencing facility UDSC, University of Delhi, New Delhi, India. Sequencing was performed using dideoxy termination method with bacterial universal primers: 27F ( $5^{\prime}$-AGAGTTTGATCCTGGCTCAG-3 $\left.{ }^{\prime}\right)$ and 1492R ( $5^{\prime}$ GGCTACCTTGTTACGACTT- $3^{\prime}$ ). The obtained sequences were combined with BioEdit program. The resultant $16 \mathrm{~S}$ rRNA sequence was compared with the representative sequences of bacterial organisms from GenBank and aligned using CLUSTAL W (Thompson et al. 1994). The 16S-rRNA sequence was submitted to NCBI. Phylogenetic analyses were carried out with maximum composite likelihood method (Felsenstein 1981) using MEGA version 5 (Tamura et al. 2011).

\section{Substrate utilization}

Substrate utilization of strain 29D was performed to examine its ability to grow on different substrates. Six substrates were chosen including methanol, diethyl phthalate (DEP), dioctyl phthalate (DOP), monobutyl phthalate (MBP), diisodecyl phthalate (DIDP), benzyl butyl phthalate (BBP) and protocatechuic acid (PC). Substrate concentration was $2000 \mathrm{mg} / \mathrm{l}$. Growth of strain 29D was measured with Perkin Elmer Lambda $25 \mathrm{UV} /$ vis spectrophotometer at $600 \mathrm{~nm}$.

\section{Kinetics and stoichiometry of DBP degradation by strain 29D}

For degradation studies, strain 29D was inoculated in MSM and PAEs-contaminated samples and flasks were incubated at $30{ }^{\circ} \mathrm{C}$ and 180 revolution per minute in an incubator. Samples for residual DBP analysis and metabolic intermediates identification were collected every $24 \mathrm{~h}$. Collected samples were extracted with ethyl acetate in 1:1 ratio and residues were dissolved in methanol. The obtained extract was filtered through a $0.22 \mu \mathrm{m}$ membrane filter and the filtrate was transferred to an autosampler vials for HPLC and gas chromatography analysis (Jin et al. 2010). For HPLC analysis of the extracts, $20 \mu \mathrm{l}$ of the filtrate was injected to the Shimadzu HPLC system. Analysis of the samples was performed using Ascentis ${ }^{\circledR}$ C 18 column, $5 \mu \mathrm{m}$, $25 \mathrm{~cm} \times 4.6 \mathrm{~cm}$ from Sigma-Aldrich. A gradient program having two mobile phases, a water/acetonitrile (15:85) v/v and B $100 \%$ acetonitrile, was used. Time programing was: 0-3 min a $100 \%$ A, 6.5-19.5 min $100 \%$ B. A total flow rate of $0.6 \mathrm{ml} / \mathrm{min}$ was maintained. Run time of the samples was $45 \mathrm{~min}$. DBP was detected using a UV detector at $225 \mathrm{~nm}$ (Thuren 1986). Residual DBP in the samples was quantified by preparing a standard curve for DBP (Park et al. 2016). Metabolic intermediates for DBP degradation were identified by the GC-MS system at Advanced Instrumentation Research Facility, Jawaharlal Nehru University, New Delhi, India, with column temperature of $100{ }^{\circ} \mathrm{C}$, injection temperature $250{ }^{\circ} \mathrm{C}$ and total flow $16.3 \mathrm{ml} / \mathrm{min}$. For calculation of biomass in terms of dry weight, bacterial cells were harvested and filtered with $0.45 \mu \mathrm{m}$ membrane filter and dried in an oven at $100{ }^{\circ} \mathrm{C}$. The dried biomass was measured with a weighing balance (Bratbak and Dundas 1984).

\section{Identification of PAEs-degrading genes}

Genes responsible for phthalate esters degradation from the strain 29D were identified by PCR. Primers known for PAEs degradation were synthesized and amplified (Table 2). The programing used for the PCR thermocycler was: 5 min at $95^{\circ} \mathrm{C}, 30$ cycles of $30 \mathrm{~s}$ at $95{ }^{\circ} \mathrm{C}, 30 \mathrm{~s}$ at $\mathrm{Tm}$ of corresponding primers, $90 \mathrm{~s}$ at $72{ }^{\circ} \mathrm{C}$ and final extension for $7 \mathrm{~min}$ at $72^{\circ} \mathrm{C}$ (Han 2008). Gel-purified amplification products were sequenced at the DNA sequencing facility UDSC, University of Delhi, New Delhi, India. Sequencing of the amplicons was performed by specific primers for each gene and amplicons were cloned in M13 vector.

\section{Statistical analysis}

Statistical analysis of DBP degradation was performed by $F$ test and one-way ANOVA with three replicates data using data analysis tool pack in Microsoft excel. For analysis, the hypothesis was made at the $5 \%$ level of significance to calculate $P$ and $F$ values.

\section{Results and discussions}

\section{Isolation, characterization and identification of the bacteria}

Cells of the strain 29D were rod shaped, Gram negative, aerobic and without flagella, forming round and creamy 
colonies on agar plates. The cells grow on MSM with $1 \%$ methanol. Strain 29 D was catalase and oxidase positive which is the characteristic of bacteria form of the genus Methylobacillus (Doronina et al. 2004; Urakami and Komagata 1986; Anthony 1982; Lidstrom 2006). Negative results were obtained for nitrate production, urease activity, $\mathrm{H}_{2} \mathrm{~S}$ production, ammonia production, methyl red, VogesProskauer and starch hydrolysis. The strain was positive for indole production, lysine utilization and $\beta$-galactosidase activity. It was resistant to streptomycin $\left(100 \mu \mathrm{g} \mathrm{ml}^{-1}\right.$ and susceptible to ampicillin $\left(10 \mu \mathrm{g} \mathrm{m}^{-1)}\right.$, penicillin $\left(10 \mu \mathrm{g} \mathrm{ml}^{-1}\right.$, kanamycin $\left(10 \mu \mathrm{g} \mathrm{ml}^{-1)}\right.$, tetracycline $\left(10 \mu \mathrm{g} \mathrm{ml}^{-1}\right)$, and chloramphenicol $\left(10 \mu \mathrm{g} \mathrm{ml}^{-1)}\right.$. SEM at $20 \mathrm{KX}$ revealed that strain 29D was rod shaped, smooth, without flagella with length $\sim 2 \mu \mathrm{m}$ and width $\sim 0.2 \mu \mathrm{m}$. TEM of strain 29D at $20 \mathrm{KX}$ revealed the presence of the outer membrane, peptidoglycan layer and plasma membrane (Fig. 1).

On comparison with the 16S-rRNA gene sequence of strain 29D, it found maximum identity with Methylobacillus arboreus clone SY117 (Accession No. KM041246.1). The strain 29D was designated as Methylobacillus sp. V29b and the obtained sequence was submitted to NCBI accession No. KM219114. The phylogenetic relationship of Methylobacillus sp. V29b is presented in Fig. 2.

\section{DBP biodegradation by Methylobacillus sp. V29b in MSM and contaminated samples}

Biodegradation experiments were conducted by growing Methylobacillus sp. V29b in MSM supplemented with DBP at $2000 \mathrm{mg} / \mathrm{l}$. To quantify the residual DBP in the bacterial culture, samples were collected every $24 \mathrm{~h}$ and quantified using HPLC. Figure $3 \mathrm{a}$ presents the relationship between the growth of Methylobacillus sp. V29b and DBP degradation. Figure $3 \mathrm{~b}$ presents the degradation of DBP in the PAEs-contaminated sample from a landfill site at Ghazipur, New Delhi, India. The amount of DBP quantified in contaminated samples was $441 \mathrm{mg} / \mathrm{l}$. From Fig. 3a, it was observed that from the initial DBP concentration of $1997 \mathrm{mg} / \mathrm{l}$, Methylobacillus sp. V29b degraded half DBP in $120 \mathrm{~h}$ and only $590.40 \mathrm{mg} / \mathrm{l}$ DBP was left after $192 \mathrm{~h}$. Therefore, $70.5 \%$ of DBP was degraded in $192 \mathrm{~h}$. From Fig. 3b, it may be observed that the Methylobacillus sp. V29b degraded half of the initial amount DBP in $96 \mathrm{~h}$ and $64.5 \%$ the initial amount of DBP in $144 \mathrm{~h}$.

\section{Biodegradation kinetics and DBP degradation stoichiometry}

Researchers have reported degradation kinetics using various models. Degradation kinetics of organic pollutants was explained by first-order equations (Lu et al. 2009; Xu et al. 2005; Zeng et al. 2004). A second-order equation was also reported for degradation of phthalate esters by algae Chlorella pyrenoidosa (Yan et al. 1995). A modified Gompertz model was used to describe the effect of initial DBP concentration on DBP biodegradation by Gordonia sp. QH-11(Jin et al. 2012). Haldane substrate inhibition model was used to explain DBP degradation in a continuous culture system (Wang et al. 1998). DBP biodegradation kinetics by Methylobacillus sp. V29b was explained by drawing a plot of specific growth rate $(\mu)$ and DBP concentration $\left(S_{\text {av }}\right)$ (Fig. 4). It was observed that as the concentration of DBP was increased, there was increase in specific growth rate, but when DBP concentration reached $1900 \mathrm{mg} / \mathrm{l}$, there was a decline in the specific growth rate. This behavior was explained by the growth inhibition model. Equation (1) represents the Monod model for growth inhibition. The calculated maximum specific growth $\left(\mu_{\max }\right)$ and half-velocity constant $\left(K_{\mathrm{s}}\right)$ were: $0.07 \mathrm{~h}^{-1}$ and $998.2 \mathrm{mg} / \mathrm{l}$, respectively.

Monod model:

$\mu=\frac{\mu_{\max } \times S}{\left(K_{\mathrm{s}}+S\right)}$,
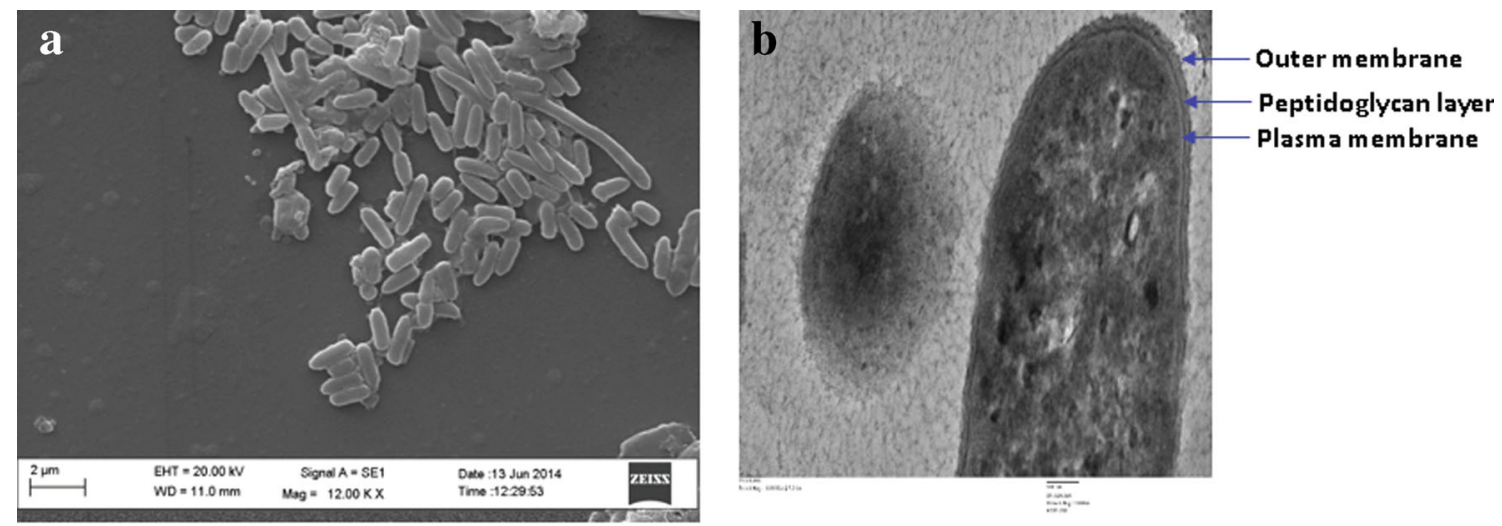

Fig. 1 a Scanning electron micrograph of strain 29D. Scale bar $2 \mu \mathrm{m}$. b Transmission electron micrograph of strain 29D. Scale bar 100 nm 


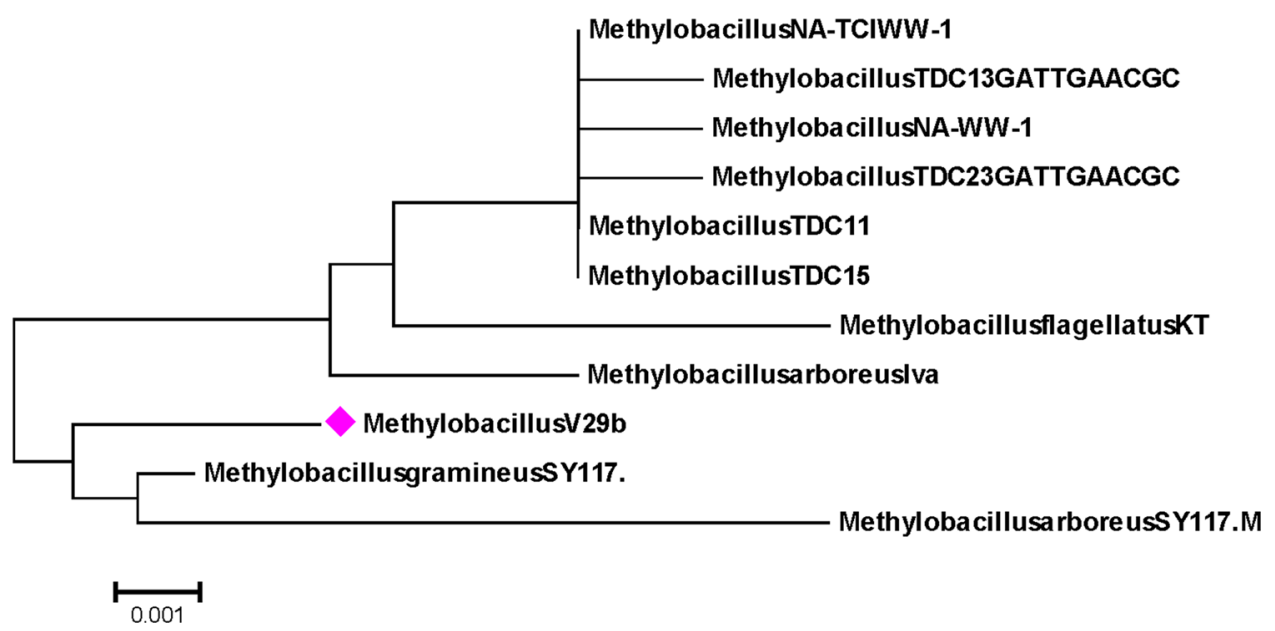

Fig. 2 Phylogenetic tree of Methylobacillus sp. V29b. The evolutionary history was inferred using the UPGMA method. The optimal tree with the sum of branch length $=0.05032880$ is shown. The percentage of replicate trees in which the associated taxa clustered together in the bootstrap test (500 replicates) are shown above the branches. The tree is drawn to scale, with branch lengths (below the branches) in the same units as those of the evolutionary distances used to infer the phylogenetic tree. The evolutionary distances were computed using the maximum composite likelihood method and are

where $\mu$ is the specific growth rate of the microorganism, $\mu_{\max }$ the maximum specific growth rate of the microorganism, $S$ the concentration of the limiting substrate for growth and $K_{\mathrm{S}}$ the half-velocity constant.

Values of the coefficients:

$\mu_{\max }=0.07 \mathrm{~h}^{-1}$,

$K_{\mathrm{s}}=998.2 \mathrm{mg} / \mathrm{l}$,

Yield $=0.43$.

Stoichiometry for DBP utilization and biomass formation (Shuler and Kargi 2002) is presented in Eq. (2):

$$
\begin{array}{rr}
50 \mathrm{C}_{16} \mathrm{H}_{22} \mathrm{O}_{4}+893 \mathrm{O}_{2}+20 \mathrm{NH}_{3} & \rightarrow 20 \mathrm{C}_{5} \mathrm{H}_{7} \mathrm{O}_{2} \mathrm{~N} \\
+546 \mathrm{H}_{2} \mathrm{O} & +700 \mathrm{CO}_{2} . \\
\mathrm{DBP} & \text { Biomass }
\end{array}
$$

\section{Identification of metabolic intermediates}

Determination of the metabolic intermediates for DBP degradation was performed by analysis of the GC-MS results. Four metabolic intermediates dibutyl phthalate (DBP), monobutyl phthalate (MBP), phthalic acid (PA), and pyrocatechol (PC) were detected during DBP degradation by comparing the mass spectrum at a particular retention time with published mass spectra from the National Institute of Standards and Technology (NIST) database. Figure 5 presents the HPLC peaks and structure of the identified metabolic intermediates from GC-MS. It was observed that with time the length of the DBP peak was decreased, while the in the units of the number of base substitutions per site. Codon positions included were $1 \mathrm{st}+2 \mathrm{nd}+3 \mathrm{rd}+$ noncoding. All positions containing gaps and missing data were eliminated from the dataset (Complete deletion option). There were a total of 1281 positions in the final dataset. Phylogenetic analyses were conducted in MEGA5. The values such as 0.002 and 0.004 denote the evolutionary distance between different species and values such as 99 and 100 denote the similarities between different species

peak lengths of the MBP and PA was increased and on day 8 the peak length was highest for pyrocatechol (PC). The identified intermediates suggest that DBP was converted to MBP, which was converted to PA. The final product of the reaction was $\mathrm{PC}$. The positive result for Rothera's reaction confirms the benzene ring cleavage.

Few studies reported that PAEs degradation was mediated by a pathway where they are first converted to its monoester by esterase and then to phthalic acid (PA). PA is then transformed to carbon dioxide and water via an intermediate known as protocatechuate (Benckiser and Ottow 1982; Eaton and Ribbons 1982; Engelhardt and Wallnöfer 1978; Wang et al. 1995a, 2003a; Xu et al. 2005, 2007, 2006). Sometimes, two ester linkages in PAEs are cleaved by two different bacteria (Cartwright et al. 2000; Li et al. 2005; $\mathrm{Li}$ and $\mathrm{Gu}$ 2007). Some studies reported the formation of phthalic acid from DBP mediated by intermediate, monobutyl phthalate (MBP) (Benckiser and Ottow 1982; Gu et al. 2004; Wang et al. 2004; Xu et al. 2005). Based on the reported studies, the identified metabolic intermediates and Rothera's test, a pathway for DBP degradation by Methylobacillus sp. V29b was proposed in Fig. 6. A similar pathway for dibutyl phthalate degradation in landfill bioreactor was reported for Enterobacter sp. T5 isolated from municipal solid waste (Fang et al. 2010). The study described the appearance of two major transient metabolites including phthalic acid (PA) and monobutyl phthalate (MBP). Pathway described for DBP degradation by Methylobacillus sp. V29b is the extension of the 
Fig. 3 a Degradation of DBP by Methylobacillus sp. V29b in MSM. b Degradation of DBP by Methylobacillus sp. V29b in the sample contaminated with DBP

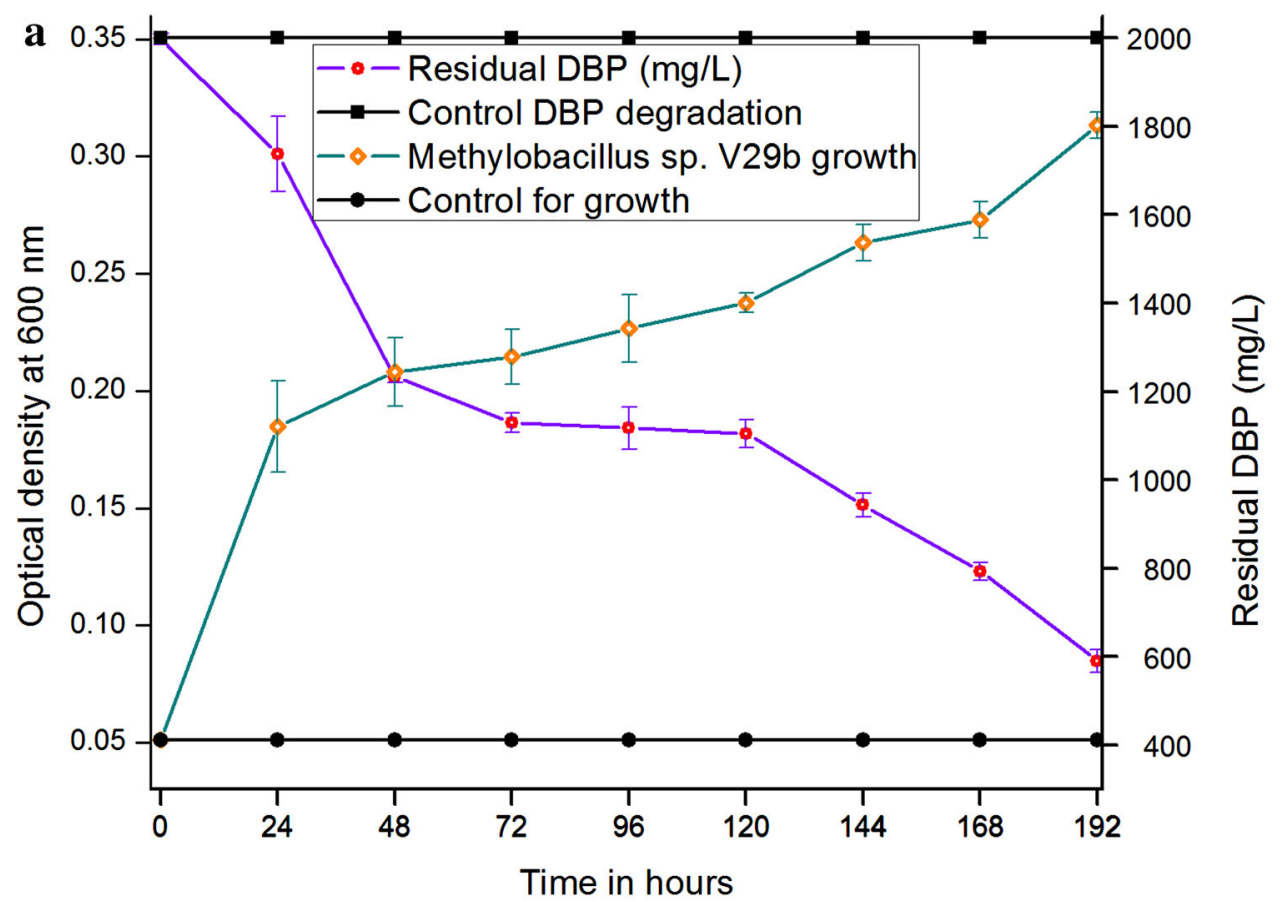

b $-\bullet-D B P$ degradation by Methylobacillus $\mathrm{sp}$. $29 \mathrm{~b}$ in field sample

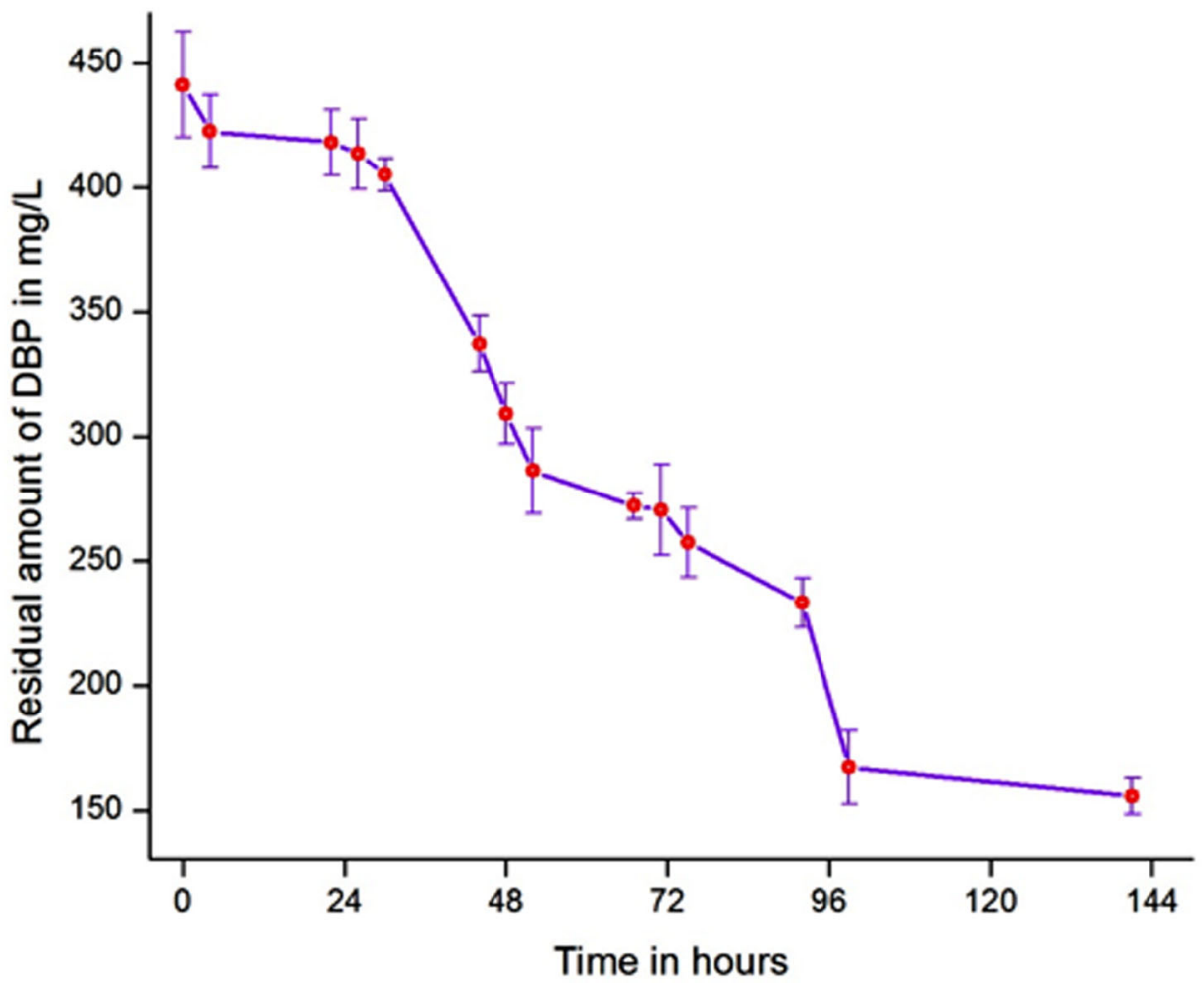

pathway proposed for DBP degradation by Enterobacter sp. T5. In Methylobacillus sp. V29b DBP, degradation of one more metabolic intermediate pyrocatechol was identified as the final aromatic intermediate which fills the gap between PA to carbon dioxide conversion.

\section{Identification of phthalates-degrading genes}

Methylobacillus sp. V29b was able to grow on substrates protocatechuate, monobutyl phthalate, diethyl phthalate, benzyl butyl phthalate, dioctyl phthalate and dodecyl 
Fig. 4 DBP degradation kinetics for Methylobacillus sp. $V 29 b$

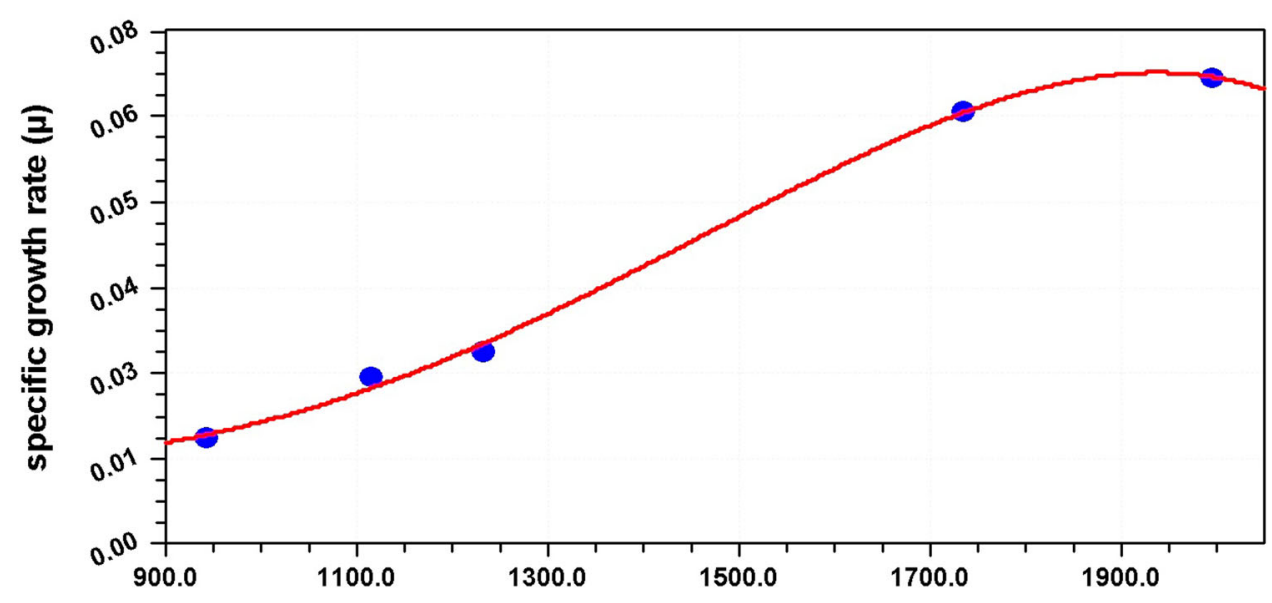

Substrate concenctration $(\mathrm{mg} / \mathrm{L})$
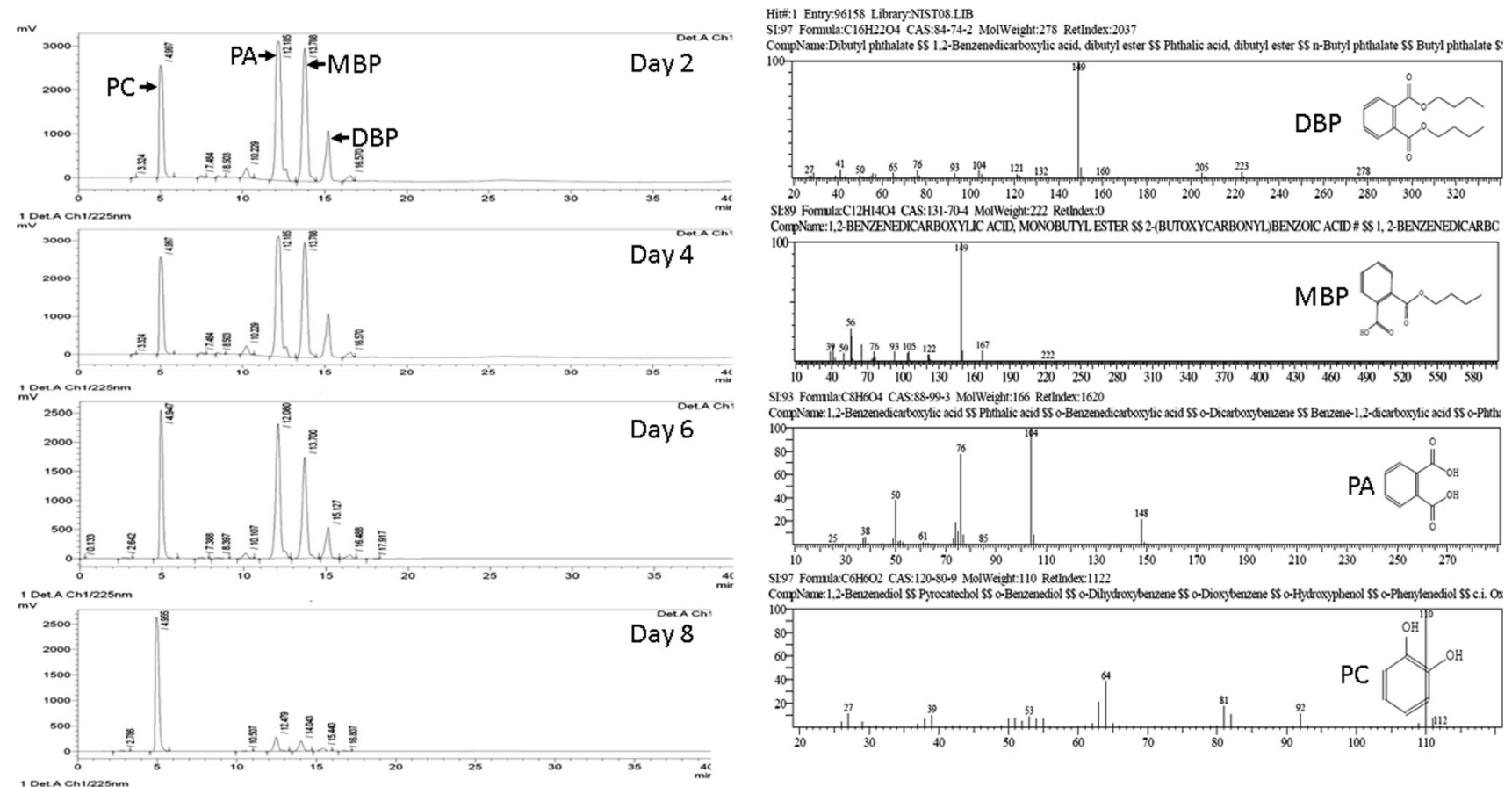

Fig. 5 DBP degradation metabolic intermediates identified by GC-MS. a HPLC chromatogram of the metabolic intermediates. b Structure and $\mathrm{m} / \mathrm{z}$ of the identified metabolic intermediates. $D B P$ dibutyl phthalate, $M B P$ monobutyl phthalate, $P A$ phthalic acid, $P C$ pyrocatechol

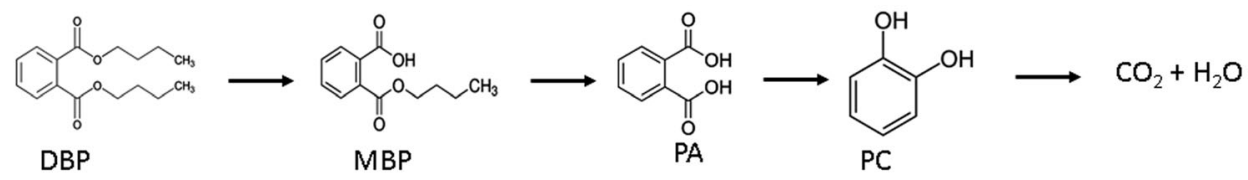

Fig. 6 A proposed biochemical pathway for DBP degradation by Methylobacillus sp. V29b. DBP dibutyl phthalate, MBP monobutyl phthalate, $P A$ phthalic acid, $P C$ pyrocatechol

phthalate (Table 1). The growth of Methylobacillus sp. V29b decreases as the length and complexity of hydrocarbon attached to the phthalate ring increases (Wang et al. 2003b). Therefore, good growth was observed in PC, MBP and DEP. To examine the possibility for degradation of different phthalate esters by Methylobacillus sp. V29b and explore the PAEs degradation pathway, PAEs-degrading genes were amplified. Table 2 presents the list of primers 
Tabel 1 Growth of Methylobacillus sp. V29b in different substrates

\begin{tabular}{ll}
\hline Strain name & Methylobacillus $\mathrm{sp} . \mathrm{V} 29 \mathrm{~b}$ \\
\hline Methanol & + \\
PC & +++ \\
MBP & +++ \\
DEP & ++ \\
BBP & + \\
DOP & + \\
DIDP & +
\end{tabular}

$P C$ pyrocatechol, $M B P$ monobutyl phthalate, $D E P$ diethyl phthalate, $B B P$ benzyl butyl phthalate, $D O P$ dioctyl phthalate, $D I D P$ diisodecyl phthalate

selected and synthesized for gene amplification. Table 3 presents the genes amplified from Methylobacillus sp. V29b genome. Gene sequences for primers FEH, HFDH, FOXG, FOXGS and FDK were obtained from Arthrobacter sp. $68 \mathrm{~b}$ growing on phthalic acid as the sole carbon source (Stanislauskienè et al. 2011). Gene sequence for the primer transporter ATPase was obtained from alkylbenzene-degrading Rhodococcus sp. strain DK17 which utilizes phthalate and terephthalate as growth substrates ((Choi et al. 2005). Gene sequences for the primers oph-A1, -A2, B, -C, -D, -H, -R, Tph-A2, -A3, and -B were obtained from the bacteria-degrading phthalate, isophthalate and terephthalate (Han 2008).

Biodegradation of phthalate esters is initiated by their transport inside the cell by phthalate permease (oph-D) which induces phthalate 4,5 dioxygenase. They belong to major facilitator superfamily with 12 hydrophobic membrane-spanning helices. Phthalate permeases are reported as transport enzymes (Eaton 2001; Keyser et al. 1976). Permeases from $P$. putida NMH102-2 and $B$. cepacia ATCC 17616 found similarity with anion:cation symporter family (Chang and Zylstra 1999). Permeases have reported multiple genes and have catabolic operons (Chang and Zylstra 1999; Eaton 2001; Sasoh et al. 2006; Wang et al. 1995b). Phthalate dioxygenase (oph-A1) catalyzes the incorporation of two hydroxyl groups on the phthalate ring to yield phthalate dihydrodiols (Eaton 2001; Keyser et al. 1976). Primer oph-A1 was used to amplify the enzyme called phthalate dioxygenase reductase (PDR). PDR is an iron sulfur flavoprotein which utilizes flavin mononucleotide (FMN) to accomplish electron transfer from reduced nicotinamide adenine nucleotide (NADH) to the one-electron acceptor, [2Fe-2S] (Correll et al. 1992). Phthalate-4,5 dioxygenase action produces cis-4,5-dihydroxy-4,5-dihydrophthalate, which is dehydrogenated by cis-phthalate dihydrodiol dehydrogenase (oph-B) to 4,5dihydroxyphthalate. Decarboxylation of 4,5-dihydroxyphthalate by 4,5-dihydroxyphthalate decarboxylase (oph-C) produces 3,4-dihydroxybenzoate, also known as protocatechuate (Batie et al. 1987; Chang and Zylstra 1998; 1999; Pujar and Ribbons 1985). Protocatechuate is one of the important intermediates in various pathways including phthalates (Eaton 2001). Protocatechuate then enters Krebs cycle after conversion to pyruvate and carbon dioxide. Protocatechuate is also present in the benzoate degradation pathway (Choi et al. 2005). Oph-H codes for a protein known as hemerythrin-like metal-binding protein. Hemerythrins are non-heme oxygen-binding proteins and they bind oxygen with a di-iron centre (Stenkamp 1994).

Table 2 Primers used for identification of PAEs-degrading genes

\begin{tabular}{lll}
\hline Primer name & Gene name & References \\
\hline Oph-A1 & 3,4-Dioxygenase oxygenase component large subunit & (Han 2008) \\
Oph-A2 & 3,4-Dioxygenase oxygenase component small & (Han 2008) \\
Oph-B & Phthalate dihydrodiol dehydrogenase & (Han 2008) \\
Oph-C & 3,4-Dihydroxyphthalate decarboxylase & 2008) \\
Oph-D & d-Galactonate transporter & (Han 2008) \\
Oph-H & Hemerythrin-like metal-binding protein 2008$)$ \\
Oph-R & Transcriptional regulator, MarR family & (Han 2008) \\
FEH & Phthalic ester hydrolase & (Stanislauskiene et al. 2011) \\
HFDH & 3,4-Dihydroxy-3,4-dihidrophthalate dehydrogenase & (Stanislauskiene et al. 2011) \\
FOXG & Phthalate dioxygenase large and small subunits & (Stanislauskiene et al. 2011) \\
FOXGS & Ferredoxin and reductase subunits & (Stanislauskienė et al. 2011) \\
FDK & 3,4-Dihidroxyphthalate-2-decarboxylase & (Stanislauskiene் et al. 2011) \\
Ptr A & Transporter ATPase & (Choi et al. 2005) \\
Tph-A2 & Terephthalate 1,2-dioxygenase oxygenase component large subunit & (Han 2008) \\
Tph-A3 & Terephthalate 1,2-dioxygenase oxygenase component small subunit & (Han 2008) \\
Tph-B & Terephthalate dihydrodiol dehydrogenase & (Han 2008) \\
\hline
\end{tabular}


Table 3 Phthalate-degrading genes identified from Methylobacillus sp. V29b genome

\begin{tabular}{llll}
\hline Amplicons & Primer name & Name of the gene & Amplicon size \\
\hline 84 & Tph-B-F2,R2 & Terephthalate dehydroxygenase & $500 \mathrm{~kb}$ \\
85 & Tph-B-F1,R1 & Terephthalate dehydroxygenase & $800 \mathrm{~kb}$ \\
86 & Oph-A1 & Phthalate dioxygenase & $800 \mathrm{~kb}$ \\
87 & Oph-D & Phthalate permease & $1 \mathrm{~kb}$ \\
89 & Oph-C & Phthalate decarboxylase & $1 \mathrm{~kb}$ \\
93 & Tph-B-F2,R3 & Terephthalate dehydroxygenase & $500 \mathrm{bp}$ \\
95 & Oph-H & Hemerythin-like metal-binding protein & $200 \mathrm{bp}$ \\
99 & Oph-B & Phthalate dehydrogenase & $500 \mathrm{bp}$ \\
\hline
\end{tabular}

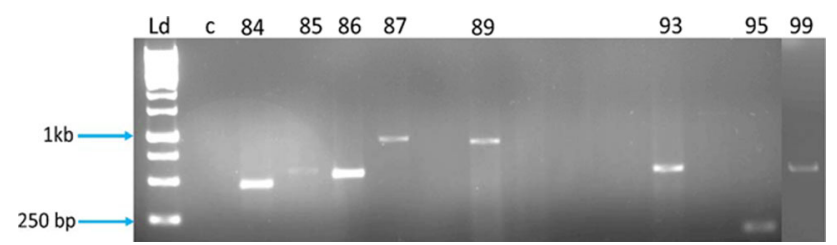

Fig. 7 Phthalate esters-degrading genes amplified form the genome of Methylobacillus sp. V29b. Ld-ladder, c-control, 84, 85 and 93-TphB, 86-oph-A1, 87-oph-D, 89-oph-C, 95-oph-H, an 99-oph-B

They occur in invertebrates Sipunculida (peanut worms), Brachiopoda (lamp shells) Priapulida (priapulid worms) and some Annelida (segmented worms, including leeches and polychaete worms) (Klippenstein et al. 1968; Loehr et al. 1978; Long et al. 1992). Hemerythrin-like proteins were reported in prokaryotes, specifically Methylococcus capsulatus and Desulfovibrio Vulgaris, and it was proposed that the oxygen-binding domain acted as an oxygen sensor (Xiong et al. 2000). Genes for hemerythrin-like metalbinding proteins were amplified using oph-H primer from the bacteria-degrading phthalate, isophthalate and terephthalate. They have been found in cluster with genes responsible for phthalate degradation, but their specific function in PAEs degradation is uncertain (Han 2008). Terephthalate metabolism is initiated by double hydroxylation at the position 1 and 2 of the ring by terephthalate 1,2 dioxygnenase (Tph-B) to produce 2-hydro-1,2-dihydroxy terephthalic acid (Choi et al. 2005; Schläfli et al. 1994). 2-Hydro-1,2-dihydroxy terephthalic acid is further metabolized to 3,4-dihydroxybenzoate (Vamsee-Krishna et al. 2006; Wang et al. 1995b). Figure 7 presents the amplified gene products for phthalate ester-degrading genes.

This study is the first to report the isolation and characterization of a Gram-negative bacterium form of the genus Methylobacillus-degrading DBP. Bacteria from the genus Methylobacillus are methylotrophs and have the ribulose monophosphate (RuMP) pathway for formaldehyde assimilation (Bratina et al. 1992; Doronina et al.
2004; Urakami and Komagata 1986). The isolated Methylobacillus sp. V29b not only grows on methanol, but is able to grow on other substrates, such as protocatechuate, monobutyl phthalate, diethyl phthalate, benzyl butyl phthalate, dioctyl phthalate and diisodecyl phthalate. DBP degradation was reported by Sphingmonas sp. DK4 (5 mg/l) (Chang et al. 2004), Pseudomonas fluorescens B-1(2.5 \& 10) (Xu et al. 2005), Acinetobacter lwoffii $(1000 \mathrm{mg} / \mathrm{l})$ (Hashizume et al. 2002), Corynbacterium nitilophius G11 (100 mg/l), $R$. rhodochrous G2, G7 (100 mg/l) (Chao et al. 2006) and R. Coprophilus G5, G9 (100 mg/l). Methylobacillus sp. V29b was able to degrade $1997 \mathrm{mg} / \mathrm{l} \mathrm{DBP}$, which is very high reported till so far. Degradation kinetics of organic pollutants were explained by first-order equations ( $\mathrm{Lu}$ et al. 2009; Xu et al. 2005; Zeng et al. 2004), second-order equation (Yan et al. 1995), modified Gompertz model (Jin et al. 2012) and Haldane model (Wang et al. 1998). Methylobacillus sp. V29b demonstrated DBP degradation by the Monod model for growth inhibition, which is a new perspective to present the degradation of pollutants. While a majority of the studies are concentrated on the degradation of PAEs in minimal media (Chao et al. 2006; Fang et al. 2010; Wu et al. 2010a; Wu et al. 2010b), this study focuses on the degradation of DBP in contaminated samples collected from landfill sites. Landfill sites are composed of wastes from domestic, medical, pharmaceutical and industrial sources containing a variety of plastic items and PAEs. Therefore, it was selected for DBP degradation studies. It was an efficient degrader of DBP in PAEs-contaminated sample; therefore, it can be considered as a potential candidate for bioremediation of the sites contaminated with pollutants.

Acknowledgments The authors are grateful to the Jawaharlal Nehru University for providing the grant Under University with Potential of Excellence (UPOEI) scheme.

Open Access This article is distributed under the terms of the Creative Commons Attribution 4.0 International License (http:// creativecommons.org/licenses/by/4.0/), which permits unrestricted 
use, distribution, and reproduction in any medium, provided you give appropriate credit to the original author(s) and the source, provide a link to the Creative Commons license, and indicate if changes were made.

\section{References}

Anthony C (1982) Biochemistry of methylotrophs. Academic Press, Dublin

Batie CJ, LaHaie E, Ballou D (1987) Purification and characterization of phthalate oxygenase and phthalate oxygenase reductase from Pseudomonas cepacia. J Biolog Chem 262:1510-1518

Benckiser G, Ottow J (1982) Metabolism of the plasticizer di-nbutylphthalate by Pseudomonas pseudoalcaligenes under anaerobic conditions, with nitrate as the only electron acceptor. Appl Environ Microbiol 44:576-578

Bratbak G, Dundas I (1984) Bacterial dry matter content and biomass estimations. Appl Environ Microbiol 48:755-757

Bratina BJ, Brusseau GA, Hanson RS (1992) Use of 16S rRNA analysis to investigate phylogeny of methylotrophic bacteria. Int J Syst Evol Microbiol 42:645-648

Cartwright CD, Owen SA, Thompson IP, Burns RG (2000) Biodegradation of diethyl phthalate in soil by a novel pathway. FEMS Microbiol Lett 186:27-34

Chang H-K, Zylstra GJ (1998) Novel organization of the genes for phthalate degradation from Burkholderia cepacia DBO1. J Bacteriol 180:6529-6537

Chang H-K, Zylstra GJ (1999) Characterization of the phthalate permease OphD from Burkholderia cepacia ATCC 17616. J Bacteriol 181:6197-6199

Chang B, Yang C, Cheng C, Yuan S (2004) Biodegradation of phthalate esters by two bacteria strains. Chemosphere 55:533-538

Chao W, Lin C, Shiung I, Kuo Y (2006) Degradation of di-butylphthalate by soil bacteria. Chemosphere 63:1377-1383

Chen J-a et al (2007) Degradation of environmental endocrine disruptor di-2-ethylhexyl phthalate by a newly discovered bacterium, Microbacterium sp. strain CQ0110Y. Appl Microbiol Biotechnol 74:676-682

Cheung JK, Lam RK, Shi M, Gu J-D (2007) Environmental fate of endocrine-disrupting dimethyl phthalate esters (DMPE) under sulfate-reducing condition. Sci Total Environ 381:126-133

Choi KY, Kim D, Sul WJ, Chae J-C, Zylstra GJ, Kim YM, Kim E (2005) Molecular and biochemical analysis of phthalate and terephthalate degradation by Rhodococcus sp. strain DK17. FEMS Microbiol Lett 252:207-213

Colborn T, vom Saal FS, Soto AM (1993) Developmental effects of endocrine-disrupting chemicals in wildlife and humans. Environ Health Perspect 101:378

Correll C, Batie C, Ballou D, Ludwig M (1992) Phthalate dioxygenase reductase: a modular structure for electron transfer from pyridine nucleotides to [2Fe-2S]. Science 258:1604-1610. doi:10.1126/science. 1280857

Council of the European Union (1993) Council Regulation (EEC) No 793/93 of 23 March 1993 on the evaluation and control of the risks of existing substances. European Union, Copenhagen

Dai G, Cui L, Song L, Cheng J, Zhong Y, Zhao R, Wang X (2005a) Bladder epithelial cell proliferation of rats induced by terephthalic acid-calculi. Food Chem Toxicol 43:217-224

Dai $G$ et al (2005b) Induction of bladder lesion by terephthalic acid and its mechanism. Biomed Environ Sci 18:211

David RM, Moore MR, Cifone MA, Finney DC, Guest D (1999) Chronic peroxisome proliferation and hepatomegaly associated with the hepatocellular tumorigenesis of di (2ethylhexyl) phthalate and the effects of recovery. Toxicol Sci 50:195-205

Doronina NV, Trotsenko YA, Kolganova TV, Tourova TP, SalkinojaSalonen MS (2004) Methylobacillus pratensis sp. nov., a novel non-pigmented, aerobic, obligately methylotrophic bacterium isolated from meadow grass. Int $\mathrm{J}$ Syst Evol Microbiol 54:1453-1457

Eaton RW (2001) Plasmid-encoded phthalate catabolic pathway in Arthrobacter keyseri 12B. J Bacteriol 183:3689-3703

Eaton RW, Ribbons DW (1982) Metabolism of dimethylphthalate by Micrococcus sp. strain 12B. J Bacteriol 151:465-467

Engelhardt G, Wallnöfer PR (1978) Metabolism of di-and mono- $n$ butyl phthalate by soil bacteria. Appl Environ Microbiol 35:243-246

Fang C-R, Yao J, Zheng Y-G, Jiang C-J, Hu L-F, Wu Y-Y, Shen D-S (2010) Dibutyl phthalate degradation by Enterobacter sp. T5 isolated from municipal solid waste in landfill bioreactor. Int Biodeterior Biodegrad 64:442-446

Feiler H (1980) Fate of priority pollutants in publicly owned treatment works. In: Fate of priority pollutants in publicly owned treatment works. EPA

Felsenstein J (1981) Evolutionary trees from DNA sequences: a maximum likelihood approach. J Mol Evol 17:368-376

Fisher JS (2004) Environmental anti-androgens and male reproductive health: focus on phthalates and testicular dysgenesis syndrome. Reproduction 127:305-315

Gesler RM (1973) Toxicology of di-2-ethylhexyl phthalate and other phthalic acid ester plasticizers. Environ Health Perspect 3:73-79

Gray LE, Ostby J, Furr J, Price M, Veeramachaneni DR, Parks L (2000) Perinatal exposure to the phthalates DEHP, BBP, and DINP, but not DEP, DMP, or DOTP, alters sexual differentiation of the male rat. Toxicol Sci 58:350-365

Gross FC, Colony JA (1973) The ubiquitous nature and objectionable characteristics of phthalate esters in aerospace technology. Environ Health Perspect 3:37-48

Gu J, Li J, Wang Y (2004) Degradation of the endocrine-disrupting dimethyl phthalate ester isomers by aerobic microorganisms isolated from mangrove sediment. In: 4th World Water Congress. September 20-24, 2004. Marrakesh, Morocco, p 9

Han R (2008) Phthalate biodegradation: gene organization, regulation and detection. ProQuest

Hashizume K, Nanya J, Toda C, Yasui T, Nagano H, Kojima N (2002) Phthalate esters detected in various water samples and biodegradation of the phthalates by microbes isolated from river water. Biol Pharm Bull 25:209-214

Hauser R, Meeker J, Singh N, Silva M, Ryan L, Duty S, Calafat A (2007) DNA damage in human sperm is related to urinary levels of phthalate monoester and oxidative metabolites. Human Reprod 22:688-695

Huang P-C, Tien C-J, Sun Y-M, Hsieh C-Y, Lee C-C (2008) Occurrence of phthalates in sediment and biota: relationship to aquatic factors and the biota-sediment accumulation factor. Chemosphere 73:539-544

Ito $\mathrm{R}$ et al (2005) Reducing the migration of di-2-ethylhexyl phthalate from polyvinyl chloride medical devices. Int $\mathrm{J}$ Pharm 303:104-112

Jaeger RJ, Rubin RJ (1970) Plasticizers from plastic devices: extraction, metabolism, and accumulation by biological systems. Science 170:460-462

Jiao Y et al (2013) Identification and characterization of a cold-active phthalate esters hydrolase by screening a metagenomic library derived from biofilms of a wastewater treatment plant. PloS One 8:e75977

Jin D-C, Liang R-X, Dai Q-Y, Zhang R-Y, Wu X-L, Chao W-L (2010) Biodegradation of di-n-butyl phthalate by Rhodococcus 
sp. JDC-11 and molecular detection of 3, 4-phthalate dioxygenase gene. J Microbiol Biotechnol 20:1440-1445

Jin D et al (2012) Biodegradation of di-n-butyl phthalate by an isolated Gordonia sp. strain QH-11: genetic identification and degradation kinetics. J Hazard Mater 221:80-85

Jobling S, Reynolds T, White R, Parker MG, Sumpter JP (1995) A variety of environmentally persistent chemicals, including some phthalate plasticizers, are weakly estrogenic. Environ Health Perspect 103:582-587

Kaun-Yu L, Fu-Wei T, Chia-Jung W, Pei-Shan L (2004) Suppression by phthalates of the calcium signaling of human nicotinic acetylcholine receptors in human neuroblastoma SH-SY5Y cells. Toxicology 200:113-121

Keith L, Telliard W (1979) ES\&T special report: priority pollutants: Ia perspective view. Environ Sci Technol 13:416-423

Keyser P, Pujar BG, Eaton RW, Ribbons DW (1976) Biodegradation of the phthalates and their esters by bacteria. Environ Health Perspect 18:159

Klippenstein GL, Hollerman JW, Klotz IM (1968) Primary structure of Golfingia gouldii hemerythrin. Order of peptides in fragments produced by tryptic digestion of succinylated hemerythrin. Complete amino acid sequence. Biochemistry 7:3868-3878

Krauskopf L (1973) Studies on the toxicity of phthalates via ingestion. Environ Health Perspect 3:61

Li J, Gu JD (2007) Complete degradation of dimethyl isophthalate requires the biochemical cooperation between Klebsiella oxytoca $\mathrm{Sc}$ and Methylobacterium mesophilicum $\mathrm{Sr}$ isolated from wetland sediment. Sci Total Environ 380:181-187

Li L-H, Jester WF Jr, Orth JM (1998) Effects of relatively low levels of mono-(2-ethylhexyl) phthalate on cocultured sertoli cells and gonocytes from neonatal rats. Toxicol Appl Pharmacol 153:258-265. doi:10.1006/taap.1998.8550

Li J, Gu J-D, Yao J-h (2005) Degradation of dimethyl terephthalate by Pasteurella multocida Sa and Sphingomonas paucimobilis Sy isolated from mangrove sediment. Int Biodeterior Biodegrad 56:158-165

Liang D-W, Zhang T, Fang HH, He J (2008) Phthalates biodegradation in the environment. Appl Microbiol Biotechnol 80:183-198

Lidstrom ME (2006) Aerobic methylotrophic prokaryotes. In: The prokaryotes. Springer, New York, pp 618-634

Loehr J, Lammers P, Brimhall B, Hermodson M (1978) Amino acid sequence of hemerythrin from Themiste dyscritum. J Biol Chem 253:5726-5731

Long RC, Zhang J-H, Kurtz DM, Negri A, Tedeschi G, Bonomi F (1992) Myohemerythrin from the sipunculid, Phascolopsis gouldii: purification, properties and amino acid sequence. Biochimica et Biophysica Acta (BBA)-Protein Struct Mol Enzymol 1122:136-142

Lovekamp-Swan T, Davis BJ (2003) Mechanisms of phthalate ester toxicity in the female reproductive system. Environ Health Perspect 111:139

Lu Y, Tang F, Wang Y, Zhao J, Zeng X, Luo Q, Wang L (2009) Biodegradation of dimethyl phthalate, diethyl phthalate and di-nbutyl phthalate by Rhodococcus sp. L4 isolated from activated sludge. J Hazard Mater 168:938-943

Marcel YL (1973) Determination of di-2-ethylhexyl phthalate levels in human blood plasma and cryoprecipitates. Environ Health Perspect 3:119

Moore NP (2000) The oestrogenic potential of the phthalate esters. Reprod Toxicol 14:183-192

Park YN, Choi MS, Rehman SU, Gye MC, Yoo HH (2016) Simultaneous GC-MS determination of seven phthalates in total and migrated portions of paper cups. Environ Sci Pollut Res 23:10270-10275
Piersma AH, Verhoef A, te Biesebeek J, Pieters MN, Slob W (2000) Developmental toxicity of butyl benzyl phthalate in the rat using a multiple dose study design. Reprod Toxicol 14:417-425

Pujar B, Ribbons D (1985) Phthalate metabolism in Pseudomonas fluorescens PHK: purification and properties of 4, 5-dihydroxyphthalate decarboxylase. Appl Environ Microbiol 49:374-376

Rothera AC (1908) Note on the sodium nitro-prusside reaction for acetone. J Physiol 37:491-494

Sasoh M, Masai E, Ishibashi S, Hara H, Kamimura N, Miyauchi K, Fukuda M (2006) Characterization of the terephthalate degradation genes of Comamonas sp. strain E6. Appl Environ Microbiol 72:1825-1832

Schläfli HR, Weiss MA, Leisinger T, Cook AM (1994) Terephthalate 1, 2-dioxygenase system from Comamonas testosteroni T-2: purification and some properties of the oxygenase component. J Bacteriol 176:6644-6652

Schwarzbauer J, Heim S, Brinker S, Littke R (2002) Occurrence and alteration of organic contaminants in seepage and leakage water from a waste deposit landfill. Water Res 36:2275-2287

Shuler ML, Kargi F (2002) Bioprocess engineering. Prentice Hall, New York

Smith KCACWO (1955) The scanning electron microscope and its fields of application Br. J Appl Phys 6:391

Stanislauskienè R, Rudenkov M, Karvelis L, Gasparavičiūtè R, Meškienė R, Časaitė V, Meškys R (2011) Analysis of phthalate degradation operon from Arthrobacter sp. 68b biologija 57

Staples CA, Adams WJ, Parkerton TF, Gorsuch JW, Biddinger GR, Reinert KH (1997) Aquatic toxicity of eighteen phthalate esters. Environ Toxicol Chem 16:875-891

Stenkamp RE (1994) Dioxygen and hemerythrin. Chem Rev 94:715-726

Tamura K, Peterson D, Peterson N, Stecher G, Nei M, Kumar S (2011) MEGA5: molecular evolutionary genetics analysis using maximum likelihood, evolutionary distance, and maximum parsimony methods. Mol Biol Evol 28:2731-2739

Teil MJ, Blanchard M, Chevreuil M (2006) Atmospheric fate of phthalate esters in an urban area (Paris-France). Sci Total Environ 354:212-223. doi:10.1016/j.scitotenv.2004.12.083

Tepper LB (1973) Phthalic acid esters-an overview. Environ Health Perspect 3:179

Thompson JD, Higgins DG, Gibson TJ (1994) CLUSTAL W: improving the sensitivity of progressive multiple sequence alignment through sequence weighting, position-specific gap penalties and weight matrix choice. Nucleic Acids Res 22:4673-4680

Thuren A (1986) Determination of phthalates in aquatic environments. Bull Environ Contam Toxicol 36:33-40

Urakami T, Komagata K (1986) Emendation of Methylobacillus Yordy and Weaver 1977, a genus for methanol-utilizing bacteria. Int J Syst Evol Microbiol 36:502-511

Vamsee-Krishna C, Phale P (2008) Bacterial degradation of phthalate isomers and their esters. Indian J Microbiol 48:19-34. doi:10. 1007/s12088-008-0003-8

Vamsee-Krishna C, Mohan Y, Phale PS (2006) Biodegradation of Phthalate Isomers by Pseudomonas aeruginosa PP4, Pseudomonas sp. PPD and Acinetobacter lwoffii ISP4. Appl Microbiol Biotechnol 72:1263-1269. doi:10.1007/s00253-006-0413-7

Vega D, Bastide J (2003) Dimethylphthalate hydrolysis by specific microbial esterase. Chemosphere 51:663-668. doi:10.1016/ s0045-6535(03)00035-3

Vikelsøe J, Thomsen M, Carlsen L (2002) Phthalates and nonylphenols in profiles of differently dressed soils. Sci Total Environ 296:105-116

Vos P et al. (2011) Bergey's manual of systematic bacteriology: Volume 3: The Firmicutes, vol 3. Springer, Germany 
Wang YP, Gu J-D (2006) Degradability of dimethyl terephthalate by Variovorax paradoxus $\mathrm{T} 4$ and Sphingomonas yanoikuyae DOS01 isolated from deep-ocean sediments. Ecotoxicology 15:549-557

Wang J, Liu P, Qian Y (1995a) Microbial degradation of di-n-butyl phthalate. Chemosphere 31:4051-4056. doi:10.1016/00456535(95)80006-7

Wang YZ, Zhou Y, Zylstra GJ (1995b) Molecular analysis of isophthalate and terephthalate degradation by Comamonas testosteroni YZW-D. Environ Health Perspect 103:9

Wang J, Liu P, Shi H, Qian Y (1998) Kinetics of biodegradation of Di-n-butyl phthalate in continuous culture system. Chemosphere 37:257-264. doi:10.1016/S0045-6535(98)00043-5

Wang Y, Fan Y, Gu J-D (2003a) Aerobic degradation of phthalic acid by Comamonas acidovoran Fy-1 and dimethyl phthalate ester by two reconstituted consortia from sewage sludge at high concentrations. World J Microbiol Biotechnol 19:811-815

Wang Y, Fan Y, Gu J-D (2003b) Microbial degradation of the endocrine-disrupting chemicals phthalic acid and dimethyl phthalate ester under aerobic conditions. Bull Environ Contam Toxicol 71:0810-0818

Wang Y, Fan Y, Gu J-D (2004) Dimethyl phthalate ester degradation by two planktonic and immobilized bacterial consortia. Int Biodeterior Biodegrad 53:93-101. doi:10.1016/j.ibiod.2003.10. 005

Wang F, Xia X, Sha Y (2008) Distribution of phthalic acid esters in Wuhan section of the Yangtze River. China J Hazard Mater 154:317-324

Weisburg WG, Barns SM, Pelletier DA, Lane DJ (1991) 16S ribosomal DNA amplification for phylogenetic study. J Bacteriol 173:697-703

Wensing M, Uhde E, Salthammer T (2005) Plastics additives in the indoor environment - flame retardants and plasticizers. Sci Total Environ 339:19-40

Wilkinson CF, Lamb JC (1999) The potential health effects of phthalate esters in children's toys: a review and risk assessment. Regul Toxicol Pharmacol 30:140-155
Wu X-1, Wang Y-y, Liang R-x, Dai Q-y, Chao W-1 (2010a) Degradation of di- $n$-butyl phthalate by newly isolated Ochrobactrum sp. Bull Environ Contam Toxicol 85:235-237

Wu X, Liang R, Dai Q, Jin D, Wang Y, Chao W (2010b) Complete degradation of di-n-octyl phthalate by biochemical cooperation between Gordonia sp. strain JDC-2 and Arthrobacter sp. strain JDC-32 isolated from activated sludge. J Hazard Mater 176:262-268

Xiong J, Kurtz DM, Ai J, Sanders-Loehr J (2000) A hemerythrin-like domain in a bacterial chemotaxis protein. Biochemistry 39:5117-5125

XR Xu, Li HB, Gu JD (2006) Elucidation of n-butyl benzyl phthalate biodegradation using high-performance liquid chromatography and gas chromatography-mass spectrometry. Anal Bioanal Chem 386:370-375

Xu X-R, Li H-B, Gu J-D (2005) Biodegradation of an endocrinedisrupting chemical di-n-butyl phthalate ester by Pseudomonas fluorescens B-1. Int Biodeterior Biodegrad 55:9-15. doi:10. 1016/j.ibiod.2004.05.005

Xu X-R, Li H-B, Gu J-D, Li X-Y (2007) Kinetics of $n$-butyl benzyl phthalate degradation by a pure bacterial culture from the mangrove sediment. J Hazard Mater 140:194-199

Yan H, Ye C, Yin C (1995) Kinetics of phthalate ester biodegradation by Chlorella pyrenoidosa. Environ Toxicol Chem 14:931-938. doi:10.1002/etc.5620140602

Yuan S, Liu C, Liao C, Chang B (2002) Occurrence and microbial degradation of phthalate esters in Taiwan river sediments. Chemosphere 49:1295-1299

Zeng F, Cui K, Li X, Fu J, Sheng G (2004) Biodegradation kinetics of phthalate esters by Pseudomonas fluoresences FS1. Process Biochem 39:1125-1129. doi:10.1016/S0032-9592(03)00226-7

Zheng Z, He P-J, Shao L-M, Lee D-J (2007) Phthalic acid esters in dissolved fractions of landfill leachates. Water Res 41:4696-4702

Zhu J, Phillips SP, Feng Y-L, Yang X (2006) Phthalate esters in human milk: concentration variations over a 6-month postpartum time. Environ Sci Technol 40:5276-5281 